\title{
POZNÁNÍ KOŽEDĚLNÉ PRODUKCE KRÁLOVSKÉHO MĚSTA PLZNĚ V OBDOBÍ POZDNÍHO STŘEDOVĚKU A RANÉHO NOVOVĚKU NA ZÁKLADĚ NÁLEZŮ KOŽENÝCH ARTEFAKTŮ Z ODPADNÍCH JÍMEK
}

\author{
JIŘÍ ORNA - VERONIKA DUDKOVÁ
}

\begin{abstract}
Abstrakt: Primárně se př́spěvek věnuje základnímu rozboru nálezových souborů kožených artefaktů získaných při archeologickém výzkumu zásypů odpadních jímek v historickém jádru města Plzně. Na základě tohoto rozboru je predstaven stručný prehled produktů kožedělných řemesel v období pozdního středověku a časného novověku. Především se pak př́spěvek věnuje komparaci archeologických a pisemných pramenü, na jejímž základě vznikl pokus o upřesněni topografie kožedělných řemesel v prostoru královského města Plzeň ve výše uvedeném období.
\end{abstract}

Klíčová slova: Plzeň - odpadni jímky - kožené artefakty - písemné prameny - kožedělná řemesla.

The study of leather-manufacturing in the royal city of Plzen̆ in the late Middle Ages and the early modern age on the basis of the finds of leather artefacts from refuse pits

\begin{abstract}
This contribution is primarily dedicated to the basic analysis of a series of finds of leather artefacts yielded by archaeological research into the fills of refuse pits in the historical centre of the city of Plzeñ. Based on this analysis, the paper brings a brief overview of leather-crafting products in the period of the late Middle Ages and the early modern age. The article chiefly focuses on the comparison of archaeological and written sources which gave rise to the attempt to specify the topography of leather crafts in the royal city of Plzen̆ in the mentioned period.
\end{abstract}

Key words: Plzeň - refuse pits - leather artefacts - written sources - leather crafts.

\section{Úvod}

Nálezy získané archeologickými výzkumy zásypů odpadních jímek přináší cenné poznatky k dějinám každodennosti (Iggers 2002, 95-111). V historickém jádru města Plzně výzkumy těchto zahloubených objektů probíhají od roku 1963 (Nechvátal 1976). Nejvíce odpadních jímek bylo zkoumáno v letech 1967-1994 v souvislosti se sanačními úpravami prostor plzeňského podzemí. Celkově prošlo archeologickým výzkumem na 120 odpadních jímek, zhruba z 80 z nich se podařilo ze zásypu získat artefakty a ekofakty především z období pozdního středověku a raného novověku.

Př́nosem pro možnost poznání dějin každodennosti je také anaerobní prostředí a stálá vlhkost zásypu odpadních jímek. Ty umožňují zakonzervování organických materiálů, které se v archeologicky zkoumaných běžných uloženinách zpravidla příliš nedochovávají. Publikovány již byly nálezy textilních (Březinová 2007) a dřevěných (Frýda 1983; Orna 2001) artefaktů nalezených v zásypu plzeňských odpadních jímek. Poslední nezpracovanou skupinou, kterou je možné zařadit mezi organické materiály, zůstaly kožené artefakty. Z tohoto důvodu proběhlo v letech 2016-2019 v rámci ústavního úkolu Západočeského muzea v Plzni zpracování těchto artefaktů, které jsou ve sbírce historické archeologie oddělení starších dějin. Cílem tohoto ústavního úkolu bylo nejen provést základní vyhodnocení nálezových souborů kožených artefaktů z jednotlivých odpadních jímek, ale také pokusit se o komparaci archeologických zjištění a písemných pramenů, a přispět tím k poznání sociální topografie královského města Plzeň v období pozdního středověku a raného novověku.

\section{Kožedělná řemesla v Plzni v období pozdního středověku a raného novověku v písemných pramenech}

V plzeňském prostředí je hlavním problémem neúplné dochování písemných pramenů z období pozdního středověku a raného novověku. Další komplikací je pak absence kritického přijímání 
informací při jejich zpracování (Nováček 2000, 27). I přes tyto nedostatky není bezpodmínečně nutné pracovat s primárními zdroji, písemné prameny jsou zpracovány ve dvoudílném ,plzeňském diplomatáři“ uspořádaném profesorem J. Strnadem (1891; 1905) a v historiografických studiích zabývajících se sociální strukturou středověké a časně novověké Plzně (Strnad 1887; 1909; Macháček 1930; Bělohlávek 1950; Bělohlávek a kol. 1965; Bělohlávková 1989). Díky tomu je možné získat především informace o počtu řemeslníků ve městě, lokalizaci jejich domů a jména řemeslníků.

O výčet řemesel a početního zastoupení řemeslníků pracujících v Plzni s kủží v období mezi lety 1400 a 1420 se na základě písemných pramenů pokusil J. Strnad. Podle něj v té době působilo ve městě sedmnáct kožešníků (pellifices), čtyřicet dva ševců (sutores), mezi něž byli řazeni i př́íštipkáři (discalciatores), čtyři řemenáři (lorifices) a sedm sedlářů (sellatores). Vydělávání koží se věnovalo sedmnáct smrad’ařů (cerdones) a další zpracování obstarávali tři barvíři (coloratores; Strnad 1887, 14).

Na základě údajů získaných ze zápisů městské knihy soudní z let 1407-1411 uvádí J. Bělohlávková tyto počty řemeslníků: třicet dva ševců, jedenáct kožešníků, pět sedlářů, dva tobolečníci, jeden brašnář, jedenáct jirchářů a sedm koželuhů (1989, 178-181).

M. Bělohlávek vytvořil podle berní knihy přehled počtu řemeslníků, kteří byli majiteli domu, a to pro léta 1418-1470: třináct ševců, tři kožešníci, jeden řemenář a deset koželuhů $(1950,158)$.

Na základě údajů o vlastnictví domu je možno rekonstruovat rozložení řemeslníků pracujících s kůží uvnitř městských hradeb královského města Plzně v období středověku a raného novověku (Strnad 1909; Macháček 1930; tab. 1, obr. 1). Největší koncentraci řemesel je možné sledovat v severní části města u Malické (Saské) brány, v dnešních ulicích Malá a Rooseveltova. Ostatně právě Malá ulice byla označována za ulici kožešníků a později ševců (Macháček 1930, 199). O něco menší koncentrace je na východní straně města, v dnešních ulicích Pražská a Perlová. To může souviset s předpokládaným situováním dílen koželuhů na Špitálském předměstí, rozkládajícím se východně od městských hradeb (Strnad 1887, 14).

Lze předpokládat, že u domů mohla existovat dlouhodobá kontinuita řemesla. Domy čp. 76 a čp. 80 byly po celé 16. století především v majetku ševců (Macháček 1930, 217, 220), ti se stř́́dali v tomto období také ve vlastnictví domu čp. 246 (Macháček 1930, 173). Dům čp. 42a po většinu 16. století patřil kožešníkům, jako poslední vlastník je uváděn Šimon Barabáš

Tab. 1. Výčet řemeslníků pracujících v Plzni s kůžemi v období pozdního středověku a raného novověku na základě písemných pramenů.

Tab. 1 - Aufzählung der gemäß schriftlicher Quellen im Spätmittelalter und der frühen Neuzeit in Pilsen mit Leder arbeitenden Handwerker.

\begin{tabular}{|c|c|c|c|c|}
\hline Datace & Lokalita & Řemeslo & Jméno & Citace \\
\hline 1400 & čp. 96 & sedlár̆ & Petr Snorl & Strnad 1909, 61 \\
\hline do 1407 & čp. 47 & švec & Vachek & Strnad 1909,78 \\
\hline $1407-1427$ & čp. 111 & švec & Ř́ha & Strnad 1909, 62 \\
\hline $1408-1411$ & с̌p. 3 & sedlář & Fencl & Strnad 1909,78 \\
\hline 1410 & čp. 221 & kožešník & Jakeš Revs & Strnad 1909, 69 \\
\hline $1411-1424$ & čp. 3 & sedlár̆ & Petr & Strnad 1909,78 \\
\hline $1411-1445$ & čp. 33 & švec & Václav & Strnad 1909,77 \\
\hline 1412 & čp. 90 & kožešník & Matěj & Strnad 1909, 61 \\
\hline 1413 & čp. 44 & švec & Řehoř Šat & Strnad 1909,76 \\
\hline do 1418 & čp. 99 & kožešník & Bartl & Strnad 1909, 61 \\
\hline do 1423 & čp. 41 & švec & Václav Němec & Strnad 1909, 76 \\
\hline po 1423 & čp. 83 & švec & Henslík & Strnad 1909, 79 \\
\hline 1. čtvrtina 15 . století & čp. 77 & sedlář & Hanuš & Strnad 1909,80 \\
\hline
\end{tabular}




\begin{tabular}{|c|c|c|c|c|}
\hline Datace & Lokalita & Řemeslo & Jméno & Citace \\
\hline 1. čtvrtina 15 . století & čp. 57 & švec & Jindřich & Strnad 1909, 79 \\
\hline 1437 & čp. $269 / 270$ & švec & Martin & Strnad 1909, 75 \\
\hline 1439 & čp. 40 & sedláŕ & Matěj Strýček & Strnad 1909, 76 \\
\hline poč. 16. století & čp. 256 & koželuh & & Macháček 1930, 177 \\
\hline poč. 16. století & čp. 36 & koželuh & & Macháček 1930, 197 \\
\hline do 1557 & čp. 41 & kožešník & Štefle Švorc & Macháček 1930, 199 \\
\hline mezi 1513-1569 & čp. 242 & uzdař & & Macháček 1930, 172 \\
\hline 1521 & čp. 34 & kožešník & Staněk & Macháček 1930, 195 \\
\hline 1525 & с̌p. 263 & uzdař & Jiř́ík & Macháček 1930, 180 \\
\hline 1528 & čp. 45 & švec & Martin Černý & Macháček 1930, 201 \\
\hline do 1529 & čp. 42 & švec & Linhart Košt & Macháček 1930, 199 \\
\hline po 1529 & čp. 42 & kožešník & Motl & Macháček 1930, 199 \\
\hline 1532 & с̌p. 263 & koželuh & Jiří & Macháček 1930, 180 \\
\hline po 1537 & čp. 288 & koželuh & Jíra & Macháček 1930, 202 \\
\hline 1542 & čp. 111 & kožešník & Šebestián & Macháček 1930, 127 \\
\hline 1549 & čp. 4 & uzdař & Leopold & Macháček 1930, 205 \\
\hline do 1554 & čp. 43 & kožešník & Jan & Macháček 1930, 199 \\
\hline po 1554 & с̌p. 43 & švec & Matěj Kulhánek & Macháček 1930, 199 \\
\hline 1563 & с̌p. 49 & švec & Jan Housenka & Macháček 1930, 208 \\
\hline 1564 & čp. 80 & švec & Matouš Korbel & Macháček 1930, 220 \\
\hline $1569-1576$ & čp. 283 & uzdař & Matěj Macek & Macháček 1930, 187 \\
\hline 1571 & čp. 47 & koželuh & Šebestián Mestl & Macháček 1930, 208 \\
\hline 1582 & с̌p. 57 & švec & Pavel Sekyra & Macháček 1930, 211 \\
\hline 1583 & čp. 49 & švec & Jan Sochor & Macháček 1930, 208 \\
\hline 1583 & čp. 263 & měšečník & Jiřík Jošt & Macháček 1930, 180 \\
\hline před 1584 & čp. 273 & sedlář & Jiří Grajner & Macháček 1930, 184 \\
\hline 1584 & čp. 68 & švec & Linhart Hrubš & Macháček 1930, 215 \\
\hline 1584 & с̌p. 62 & koželuh & Jan Zlámal & Macháček 1930, 213 \\
\hline 1585 & čp. 35 & koželuh & Šebestián Mestl & Macháček 1930, 196 \\
\hline 1596 & čp. 44 & jircháŕ & Řehoř Raboch & Macháček 1930, 200 \\
\hline 1599 & čp. 265 & uzdař & Štefan Marek & Macháček 1930, 181 \\
\hline 1601 & čp. 52 & sedlář & Martin Pfleger (Fleger) & Macháček 1930, 209 \\
\hline 1618 & čp. 44 & kožešník & Václav Sayfrid & Macháček 1930, 200 \\
\hline 1622 & čp. 50 & jircháŕ & Ambrož Cymrmon & Macháček 1930, 209 \\
\hline 1633 & čp. 276 & kožešník & Jan Šmidt & Macháček 1930, 185 \\
\hline po 1645 & čp. 53 & švec & Jiřík Nizský & Macháček 1930, 210 \\
\hline 1648 & čp. 64 & kožešník & Jan Schmidt & Macháček 1930, 213 \\
\hline
\end{tabular}

(Macháček 1930, 199). Kožešníci jsou uváděni od roku 1542 dalších zhruba sto let jako majitelé také u domu čp. 111 (Macháček 1930, 127). Řemeslníci pracující s kůžemi se v 16. století střídali také ve vlastnictví domů čp. 47 a čp. 263 (Macháček 1930, 208, 180). V domě čp. 233 mezi lety 1513 a 1595 působili postupně sedlár̆, uzdař a švec (Macháček 1930, 167). 
U většiny vlastníků domů jsou známa také jejich jména (Strnad 1909; Macháček 1930; tab. 1). Další jména poskytují odkazy a kupní smlouvy plzeňských měšt’anů. Dne 23. července 1339 švec Wernher odkázal farnímu kostelu jednu kopu ročního platu (Strnad 1891, 48). To samé učinil v roce 1365 kožešník Meinl (Strnad 1891, 100). Hned v několika závětích je v letech 1379 a 1380 zmíněn kožešník Frencl (Strnad 1891, 135, 136, 139). V pořízení soukeníka Blahuty z 6. února 1380 je uveden kožešník Herman (Strnad 1891, 137), v závěti lékaře Ješka z 9. srpna 1380 švec Mikuláš (Strnad 1891, 141). Sedlář Václav je zmíněn v závěti Václava Pumby z 22. prosince 1386 (Strnad 1891, 168). Díky odkazu Václava z Chřelenic ze 17. ledna 1391 je znám purkmistr a kožešník Henzl (Strnad 1891, 181). V závěti Anny, vdovy po kožešníku Hermannovi, ze 17. července 1396 je uvedena Kateřina, dcera kožešníka Václava (Strnad 1891, 201, 202). Koželuh Jan Motl odkázal 9. června 1413 po třiceti kopách koželuhům Michalovi a Oldřichovi (Strnad 1891, 265, 266). Švec Kavka je zmíněn v závěti Kúny z Křimic z 20. září 1418 (Strnad 1891, 428). Kožešník Filip je uveden v listině ze 17. ledna 1433 (Strnad 1891, 359). V kupní smlouvě z 30. května 1447 figuruje koželuh Tomášek (Strnad 1891, 420, 421).

V privilegiu z 1. května 1363, kterým Karel IV. udělil Plzni právo výročního trhu, jsou zmíněny i výrobky z kůže (Strnad 1891, 92, 93). V závětích plzeňských měštanů není uvedeno prŕliš produktů kožedělných řemesel, s výjimkou těch vytvořených kožešníky. Konkrétně jde o kožich kuní (pellicium mardrinum) a rukavice (Strnad 1891, 147), kožich beránčí (Strnad 1891, 307) a sukni s liščím kožichem (Strnad 1891, 343).

\section{Charakteristika zpracovávaného souboru a metoda jeho zpracování}

Jak již bylo uvedeno, zpracovávané kožené artefakty byly získány ze zásypu odpadních jímek v historickém jádru Plzně (obr. 1). Již popsané specifické prostředí odpadních jímek sice umožnilo zachování předmětů vyrobených z organických materiálů, zejména u těch kožených však mohlo dojít k určitým postdepozičním procesům, které ovlivnily jejich zachování a následné možnosti dalšího zpracování. U usní vyzvednutých z vlhkých anaerobních prostředí se zpravidla nedochovají pigmenty a barviva (Vyskočilová-Orlita-Součková-Ševčík 2016, 119). Většina odpadních jímek sloužila také jako jímky fekální (Dudková-Orna 2013, 559), což dokládá chemický rozbor zásypu odpadní jímky 2 na pozemku čp. 232. Rozbor doložil zásadité prostředí zásypu s vysokým obsahem fosforu a hořčíku (Frýda 1981, 327-328). V tomto prostředí se předměty nacházely několik set let a to mohlo způsobit další devalvaci struktury kůže i jejího vzhledu. V současné době jsou nálezy kožených artefaktů z odpadních jímek evidovány ve sbírce historické archeologie oddělení starších dějin Západočeského muzea v Plzni. Většina z nich je součástí této sbírky několik desetiletí. Také tato skutečnost negativně ovlivnila možnosti zpracování tohoto souboru. Konzervace a preventivní konzervace kožených předmětů v minulosti obnášela především snahu o prosycení usně tukovací směsí. V současnosti se však tato metoda hodnotí jako nevhodná (Vyskočilová-Orlita-Součková-Ševčík 2016, 145). V rámci této metody byly od zařazení nálezů do sbírky používány nejrůznější konzervační prrípravky, jejichž nánosy znemožnily sledovat trasologické stopy, doklady některých výrobních postupů a také makroskopicky určit druhy usní, z kterých byl předmět vyroben. Tyto problémy byly evidovány již u předchozích snah o publikaci nálezů kožených artefaktů z Plzně (Nechvátal 1976, 117; Frýda 1981, 318-319).

Pro zpracování nálezových souborů z jednotlivých odpadních jímek byla vytvořena databáze obsahující popis a charakteristiku jednotlivých inventárních čísel. Vzhledem k odpadnímu charakteru zpracovávaných souborů a pro potřeby této studie bylo upuštěno od tradičního rozdělení do funkčních skupin (Obuv, Opasky a řemeny, Tobolky, Rukavice, Výrobní odpad, Ostatní; např. Hoch 2015a, 280). Proběhlo pouze základní rozřazení artefaktů do těchto kategorií: výrobek - dílec - výrobní odpad - neidentifikovatelné předměty.

Dílcem je v tomto př́ípadě myšlena část výrobku a není rozlišováno, zda jde o jednotlivé poškozené dílce, které byly nahrazeny novým a následně pro nepoužitelnost vyhozeny, nebo dílce $\mathrm{z}$ rozpadlých artefaktů, $\mathrm{k}$ jejichž rekonstrukci by musela přispět precizně provedená stehová 


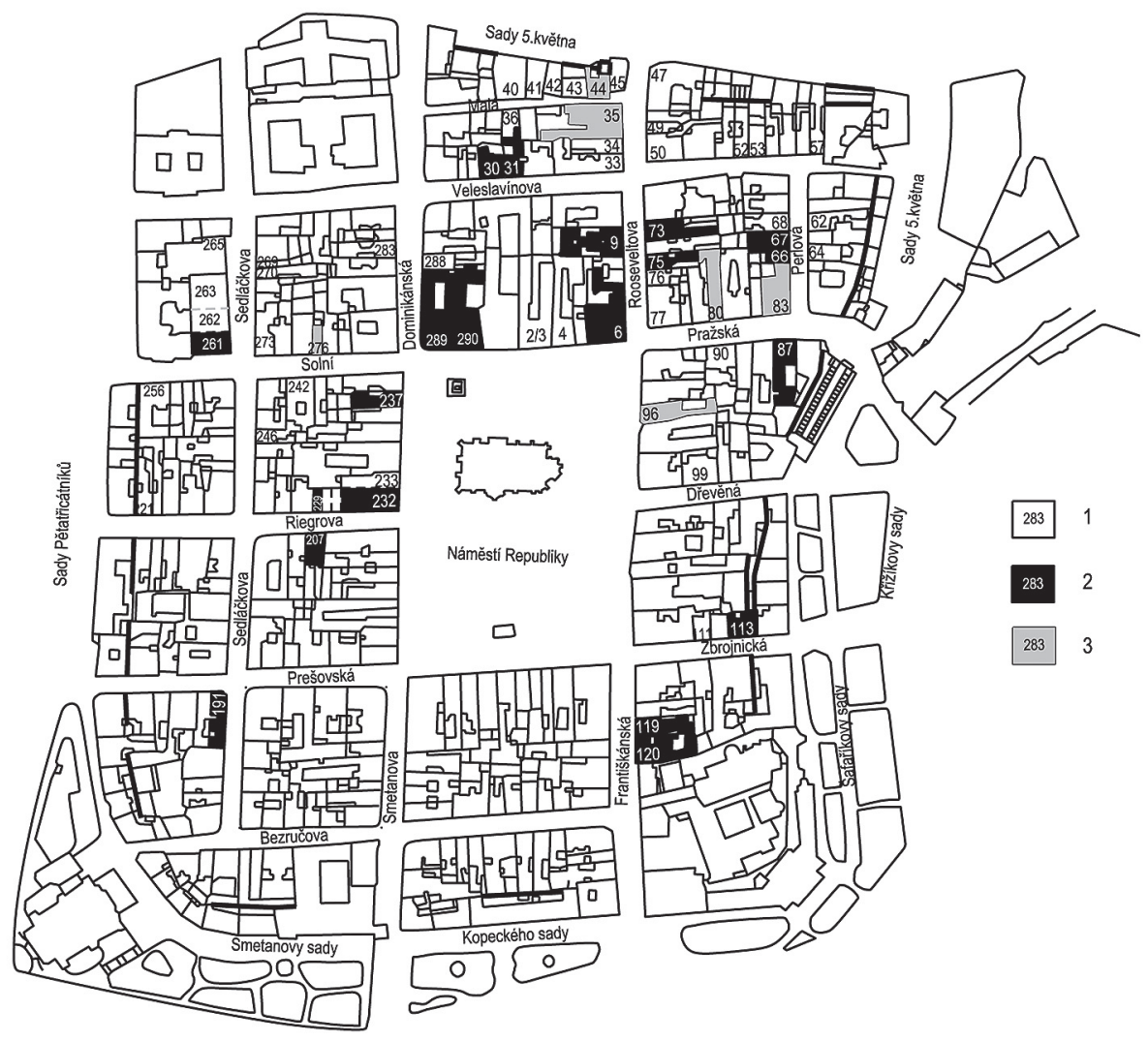

Obr. 1. Celkový plán historického centra města s vyznačením lokalit uvedených v textu. 1 - domy uvedené v písemných pramenech; 2 - archeologicky zkoumané lokality; 3 - potvrzení písemných pramenů archeologickým výzkumem. Orientováno k severu. Úprava V. Dudková.

Abb. 1. Gesamtplan des historischen Stadtzentrums mit Kennzeichnung der im Text aufgeführten Fundstellen. 1 - in schriftlichen Quellen aufgeführte Häuser; 2 - archäologisch untersuchte Fundstellen; 3 - Bestätigung der schriftlichen Quellen durch die archäologische Untersuchung. Orientierung nach Norden. Bearbeitung V. Dudková.

analýza (Hlaváček 2002, 123). Na dílcích jsou zpravidla patrné stopy výrobních postupů a je možné určit jejich původní tvar. K opravě poškozených výrobků sloužily opravné dílce. Nejčastěji opravovanou částí boty byla podešev, která se opravovala podrážkou (Hlaváček 2002, 123). K opravě svršků se používaly nástavné záplaty či opětovné sešití (Shromáždilová 2000, 41).

Soubory z jednotlivých odpadních jímek byly na základě výše uvedeného rozdělení do skupin statisticky vyhodnoceny a následně proběhl základní rozbor nalezených artefaktů. Ten měl umožnit především přiřazení fragmentů usní ke konkrétnímu kožedělnému řemeslu. Také proto, a i vzhledem k problémům s lokalizací odpadních jímek (Orna-Dudková 2016, 371), byla provedena u všech lokalit revize polohy jímky, z kterých byly artefakty získány. U několika jímek byla zjišsěna lokalizace k jinému domu.

\section{Stručný rozbor nálezového celku z hlediska kožedělných řemesel}

Mezi koženými artefakty nalezenými v plzeňských odpadních jímkách z období pozdního středověku a časného novověku mají největší zastoupení fragmenty produktů zhotovených 
ševci. Tento poměr je doložen i na řadě dalších lokalit v České republice (Čapek-Militký a kol. 2016, 337; Dejmal-Hoch 2013; Flodrová-Loskotová 1995, 553; Frolík-Sigl 1998, 112-114; Hoch 2015; 2018; Hoch-Staněk 2015; Klápště 1983, 463-465; PíckaHůrková-Schneiderwinklová 2009, 142, 143; Šmejda 1999, 186) i v zahraničí (např. Groenman-van Waateringe 1980, 116). Udává se, že fragmenty související s obuví tvoří až $90 \%$ nálezů kožených artefaktů (Klápště 1983, 463; Schnack 1994, 9). To je zřejmě způsobeno jednak poměrně nízkou životností obuvi, ale také snahami o její opravy, k nimž mohlo u jednoho páru dojít i několikrát (Grew-Neergaard 1996, 89-90). Jako důvod kvantitativně výraznějšího zachování obuvi je uváděno také její natírání tukem z důvodu zajištění poddajnosti kůže a voděodolnosti (Grew-Neergaard 2001, 89-90). Toto tvrzení je však poněkud diskutabilní, nebot' usně činěné tukem se dochovají spíše v suchém prostředí (Vyskočilová-Orlita-SoučkováŠevčík 2016, 119). Součástí obuvi mohly být také fragmenty řemínků a těsnicích pásků, tzv. okolků (Atzbach 2001, 185). Pro základní vyhodnocení dokladů obuvnické produkce z plzeňských odpadních jímek je možné využít závěry zpracování nálezů z čp. 83, čp. 232 a čp. 262 (Frýda 1981, 314-316; Nechvátal 1976, 117). Tyto nálezové soubory tvořily především prošlapané podešve (obr. 2) a nártové části se stopami použití a poškození (obr. 3). Vyhodnocení těchto souborů odpovídá historickému dobovému dělení na tzv. „krátké a dlouhé dílo“. Toto základní dělení podle výšky obuvi bylo ostatně aplikováno i na nálezy obuvi z Londýna (Gref-Neergaard 2001, 17, 20, 25), Hamburku (Kablitz 2002, 156-172, Abb. 5.) a Kolobřehu (Wywrot-Wyszkowska 2008, 43-46). Jako nízký typ obuvi byla označena škorně, která kryla nohu až nad kotník (Nechvátal 1976, 117), vyšší škorně se pak měly vyznačovat oblou špičkou a dosahovaly přibližně do půli lýtek (Frýda 1983, 315). Nově byly doloženy i fragmenty dětské obuvi, podešve dětských bot byly součástí zásypu jímky 1 u čp. 207 (obr. 4).

V současné době se pro vytváření základní typologie obuvi používá dělení podle způsobu upínání k noze (Goubitz 2001,

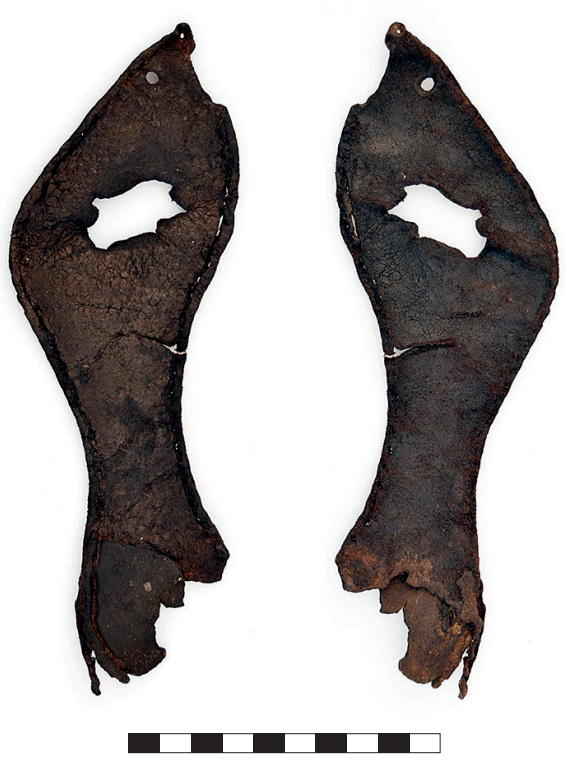

Obr. 2. Plzeň čp. 83, jímka 2. Poškozená podešev. Foto M. Zemánková, úprava I. Šlechtová.

Abb. 2. Pilsen Konskriptionsnr. 83, Abwassergrube 2. Beschädigte Sohle. Foto M. Zemánková, Bearbeitung I. Šlechtová.

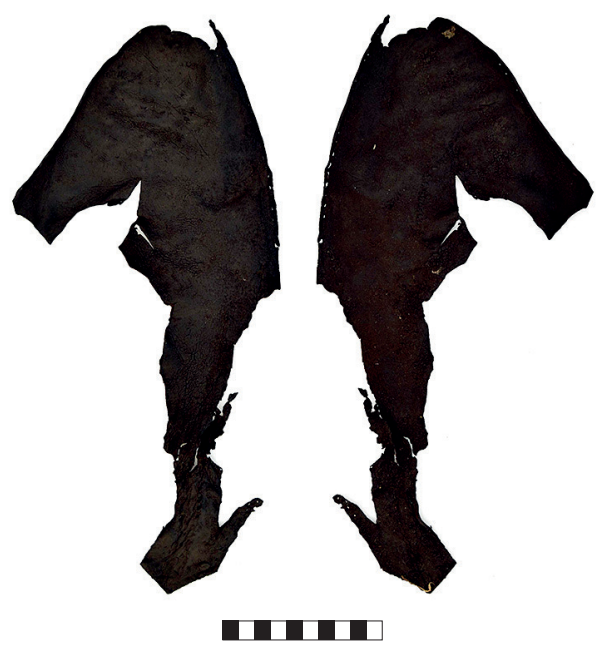

Obr. 3. Plzeň čp. 83, jímka 2. Poškozená svrchní část obuvi. Foto M. Zemánková, úprava I. Šlechtová.

Abb. 3. Pilsen Konskriptionsnr. 83, Abwassergrube 2. Beschädigtes Oberteil eines Schuhs. Foto M. Zemánková, Bearbeitung I. Šlechtová. 


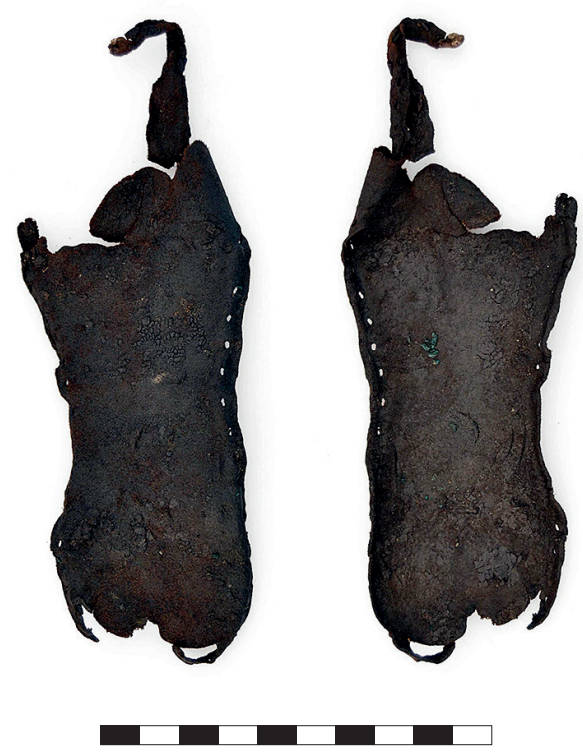

Obr. 4. Plzeň čp. 207, jímka 1. Poškozená podešev dětské obuvi. Foto M. Zemánková, úprava I. Šlechtová.

Abb. 4. Pilsen Konskriptionsnr. 207, Abwassergrube 1. Beschädigte Sohle eines Kinderschuhs. Foto M. Zemánková, Bearbeitung I. Šlechtová.
131-270) v kombinaci s typologií podle výšky střihu (např. Grew-Neergaard 2001; Schnack 1994). V blízké budoucnosti by mělo proběhnout zpracování nálezů obuvi z plzeňských odpadních jímek podle této typologie.

$\mathrm{K}$ méně často nalézaným obuvnickým produktům patří dřevěné trepky (přezůvky, pantochy) s horním koženým páskem. Ty se používaly především jako ochrana kožené obuvi při chůzi venku. V odpadní jímce 3 u čp. 232 se našel takřka kompletní exemplár se zachovaným zbytkem usňové podešve (obr. 5). Zbytek boty i dřevěná trepka jsou zakončeny nepř́iliš výrazným protažením do špičky. Méně výrazné špičky obuvi jsou předpokládány u méně luxusního obuvnického zboží. Dřevěnou platformu trepky se podařilo objevit také v zásypu odpadní jímky 1 u čp. 119 (Orna 2001). V této odpadní jímce se nacházely i kožené pásky zdobené kolky (obr. 6). Vzhledem k tomu, že jsou známy bohatě zdobené svrchní části kožených upevnění trepek (Ceynowa-Trawicka 2016, 77, 79, 80; Goubitz 2001, 12; Grew-Neergaard 2001, 94-96), není vyloučena možnost, že nalezené pásky mohly, nebo měly být součástí trepky. Dalším druhem

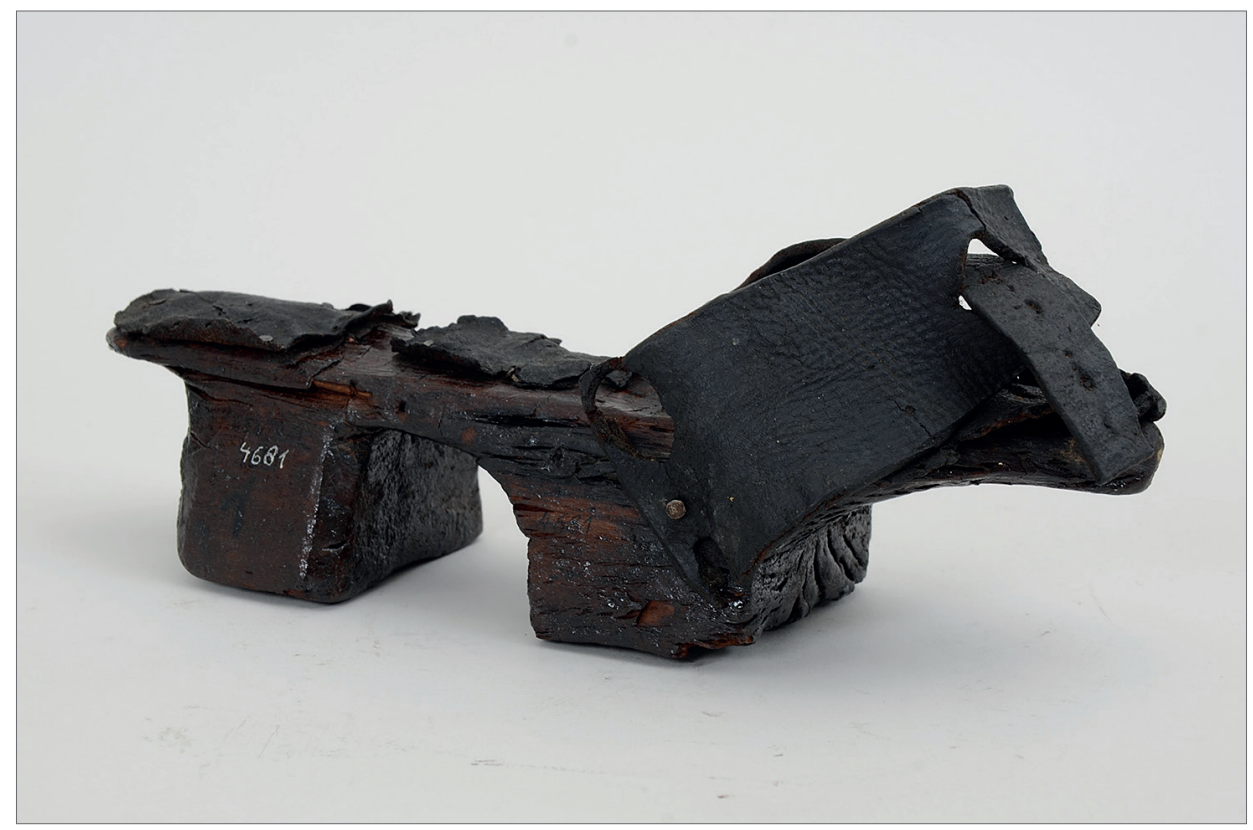

Obr. 5. Plzeň čp. 232, jímka 3. Trepka. Podle Orna 2001.

Abb. 5. Pilsen Konskriptionsnr. 232, Abwassergrube 3. Trippe. Nach Orna 2001. 
výrobku, který je možné $\mathrm{v}$ nálezech identifikovat, jsou tašky. V literatuře bývají též označovány jako tašvice (Winter 1893, 518), brašny či tobolky. Tyto názvy označují kožený artefakt, který se nosil zavěšený na opasku. To je zachyceno na ikonografiích tuzemských (např. Husa-Petráň-Šubrtová 1967, obr. 13; Wagner-Drobná-Durdík 1956, tab. 17, tab. 19, tab. 25) i zahraničních (Wagner-DrobnáDurdík 1956, tab. 79; více $\mathrm{k}$ problematice Goubitz 2009). Tobolce tvarově odpovídá nález ze zásypu jímky u čp. 262 (obr. 7); v primární publikaci nálezového souboru (Nechvátal 1976) tento předmět není uveden. Spodní úložnou část tobolky se podařilo objevit i v zásypu jímky 2 čp. 272 (obr. 8) a v jímce u čp. 96 (obr. 9). Za zadní dílec tobolky $\mathrm{s}$ negativy tří našitých vnitřních kapes lze pravděpodobně označit nález ze zásypu jímky u čp. 289 (obr. 10). Další dílec tobolky tvořený spodní zadní částí s navazující svrchní závěsnou částí pochází z jímky u čp. 80 (obr. 11).

Unikátním nálezem je pár palcových kožešinových rukavic (obr. 12). Ty byly do zásypu odpadní jímky 2 v čp. 83 uloženy ve velkém plátěném pytli. Rukavice byly vystřiženy z jednoho kusu kožešiny a sešity silnou nití. U levé rukavice chybí palcový dílec. Materiálem byla zřejmě kožešina psí nebo vlčí (Frýda 1981, 317). Podle ústního sdělení autora výzkumu byla v době nálezu na vnitřní straně rukavic zachována srst, z které byly odebrány vzorky k nerealizované analýze. Jednoduché palcové rukavice byly v České republice nalezeny také v Hradci Králové (Richter-Vokolek 1995, tab. 130:9), v Uherském Hradišti (Shromáždilová 2001, 154) a ve Veselí nad Moravou (Hoch 2015a, 289, 290, obr. 12), v zahraničí pak v Brémách (Rech 2004, 289), v polském

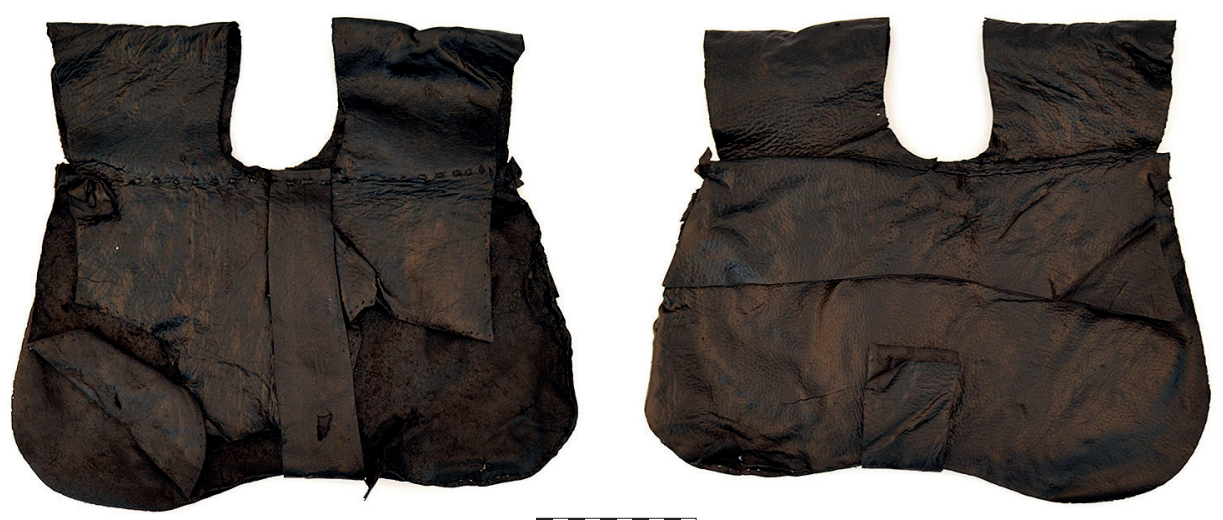

Obr. 7. Plzeň čp. 262, jímka 1. Tobolka. Foto M. Zemánková, úprava I. Šlechtová.

Abb. 7. Pilsen Konskriptionsnr. 262, Abwassergrube 1. Tasche. Foto M. Zemánková, Bearbeitung I. Šlechtová. 

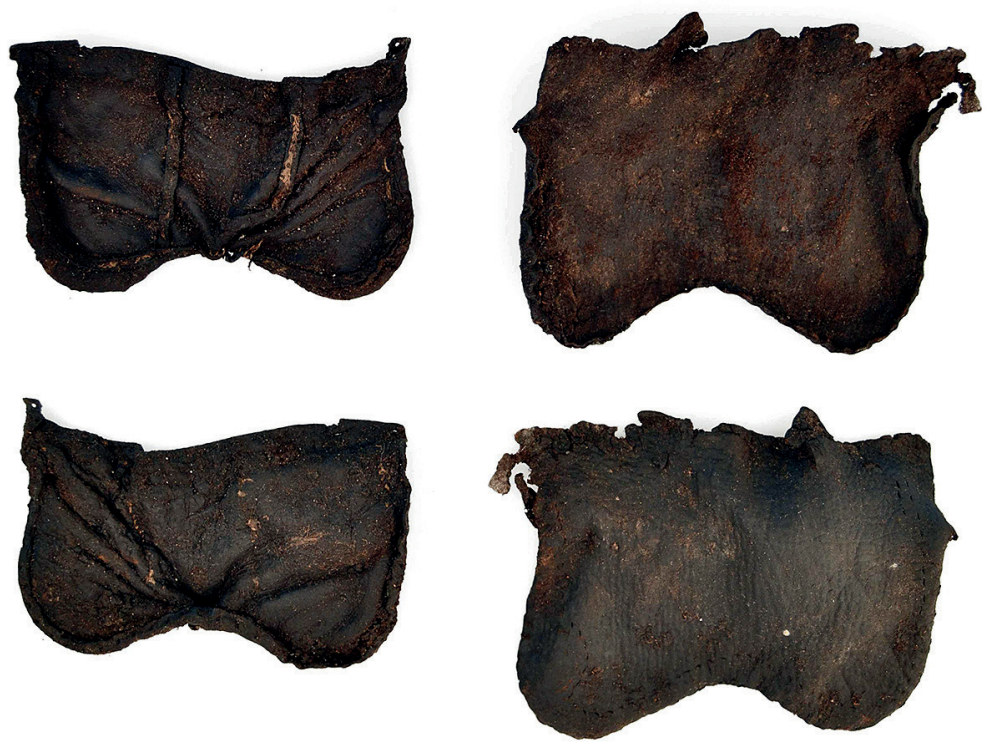

Obr. 8. Plzeň čp. 272, jímka 2. Spodní část tobolky. Foto M. Zemánková, úprava I. Šlechtová.

Abb. 8. Pilsen Konskriptionsnr. 272, Abwassergrube 2. Unteres Teilstïck einer Tasche. Foto M. Zemánková, Bearbeitung I. Šlechtová.
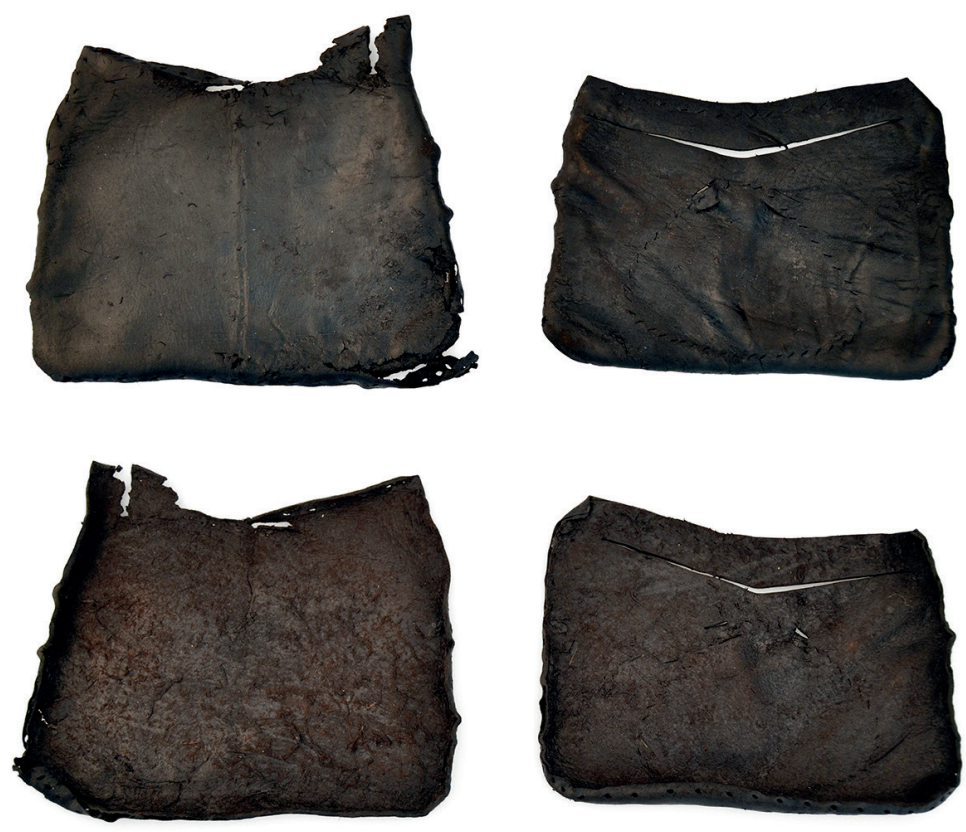

Obr. 9. Plzeň čp. 96, jímka. Spodní část tobolky. Foto M. Zemánková, úprava I. Šlechtová.

Abb. 9. Pilsen Konskriptionsnr. 96, Abwassergrube. Unteres Teilstück einer Tasche. Foto M. Zemánková, Bearbeitung I. Šlechtová. 
Kolobřehu (Wywrot-Wyszkovska 2009, ryc. 6) a v Kostnici (Schnack 1994, Taf. 45). Výrobě kožených a kožešinových rukavic se věnovali specializovaní řemeslníci rukavičníci (Petrán̆ a kol. 1985, 690), ty však písemné prameny v plzeňském prostř̌edí neuvádějí.

V jímce u čp. 96 byl nalezen koncový fragment opasku $\mathrm{s}$ dřevěnou kruhovou přezkou (obr. 13). Rozměrově a provedením takřka analogický exemplář, u nějž však byla kruhová přezka kostěná, se podařilo najít při výzkumu hradu ve Veselí nad Moravou (Hoch 2015a, 291, 293, obr. 17). Pásky zdobené prvky ze slitiny mědi získané ze zásypu jímku u čp. 289 (obr. 14) jsou zřejmě produktem pasířské dílny. Zbylé fragmenty mohou být dokladem nejen opasků, ale také řmínků z obuvi či nástavných klínků.

Lze předpokládat, že fragmenty nalezené $\mathrm{v}$ plzeňských odpadních jímkách jsou vyrobeny $\mathrm{z}$ kủže pocházející $\mathrm{z}$ hovězího dobytka. Kůže a usně z tř́isločiněné hověziny jsou ostatně nejvíce zastoupeny u dosud analyzovaých souborů (Dejmal-Hoch 2013, 668; Hlaváček 2002, 121; Shromáždilová 2000), pouze marginálně se jako materiál vyskytuje kozina (Hlaváček 2002, 121).

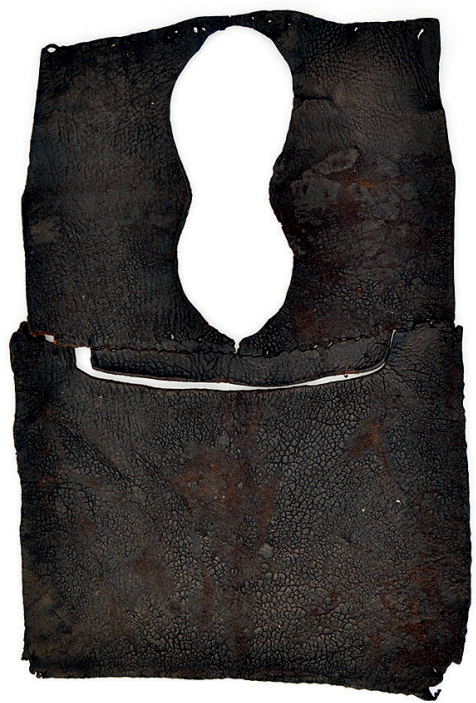

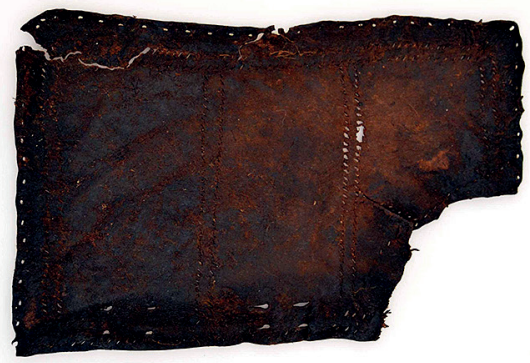

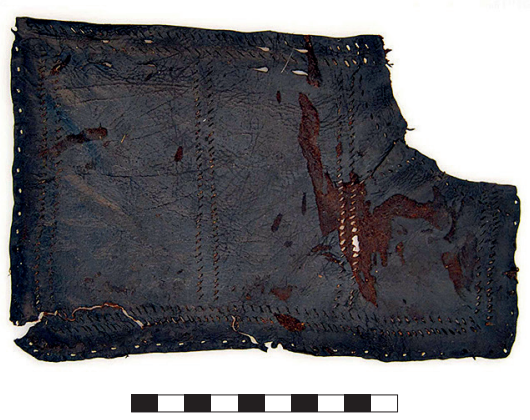

Obr. 10. Plzeň čp. 289, Dominikánská 2, jímka. Zadní dílec tobolky. Foto M. Zemánková, úprava I. Šlechtová.

Abb. 10. Pilsen Konskriptionsnr. 289, Dominikánská-Str. 2, Abwassergrube. Hinteres Teilstück einer Tasche. Foto M. Zemánková, Bearbeitung I. Šlechtová.

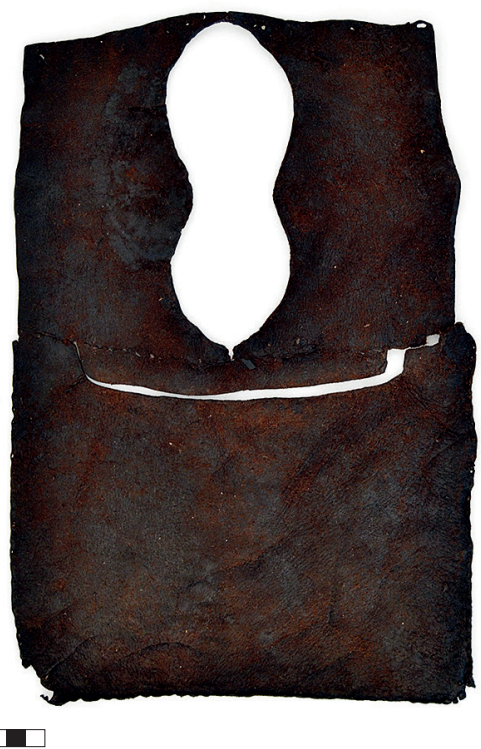

Obr. 11. Plzeň čp. 80, jímka. Dílec tobolky. Foto M. Zemánková, úprava I. Šlechtová.

Abb. 11. Pilsen Konskriptionsnr. 80, Abwassergrube. Teilstück einer Tasche. Foto M. Zemánková, Bearbeitung I. Šlechtová. 


\section{Komparace písemných a archeologických pramenů}

Fragmenty kožených artefaktů se podařilo získat ze zásypu dvaceti sedmi odpadních jímek. Ve většině z nich, konkrétně v jednadvaceti, se však podařilo evidovat méně než dvacet fragmentů. Toto nízké početní zastoupení může mít hned několik vysvětlení.

- Praktikování domácí opravy obuvi se předpokládá pro celé období středověku (Groenman-van Waateringe 1980, 117; Klápště 2002, 199; Wiklak 1960, 19). Menší počet nalezených fragmentů obuvi může být právě dokladem těchto domácích oprav.

- Řemeslník působil v domě krátce. Řemeslník nutně nemusel být majitelem nemovitosti, v Plzni je doloženo nájemní bydlení (inquilini) v tzv. zadních domech, o kterém první zachovaná zmínka pochází z roku 1407 (Bělohlávková 1989, 171). Kromě bydlení zde mohlo být provozováno řemeslo či živnost vhodná do těchto podmínek. Ještě v roce 1648 je u domu čp. 35 uváděna existence koželužské dílny, přestože tuto nemovitost vlastnil řezník Bernart Komínek, který zde provozoval i pohostinskou činnost (Macháček 1931, 196).

- Svoji roli v redukci archeologických pramenů mohly hrát také depoziční a postdepoziční procesy. Jedna jímka zřejmě sloužila obyvatelům více domů (Winter 1890, 409). To se projevilo u nálezů souvisejících s působením lékařů v čp. 289, kdy se několik málo artefaktů objevilo i v odpadní jímce sousedního čp. 288 (Dudková-Orna 2009, 507, obr. 2). I odpad z kožedělné činnosti se tedy mohl objevit, byt' v menším množství, v odpadních jímkách na sousedních parcelách. $\mathrm{Na}$ parcelách se velmi často nacházel větší počet odpadních jímek (Dudková-Orna 2013, 558, obr. 1). Také tento fakt mohl ovlivnit množství deponovaných dokladů kožedělného řemesla $v$ jímce, která prošla archeologickým výzkumem. Ještě v době aktivního využívání jímek docházelo $\mathrm{k}$ jejich občasnému a částečnému čištění, výzkumem doloženo je v čp. 187 (Nováček 2000, 15). Známé jsou však i př́ípady velmi rychlého zaplnění jímek hned po jejich vyhloubení (Nováček-Stočes-Široký-Wasková 2014, 158). K odebrání
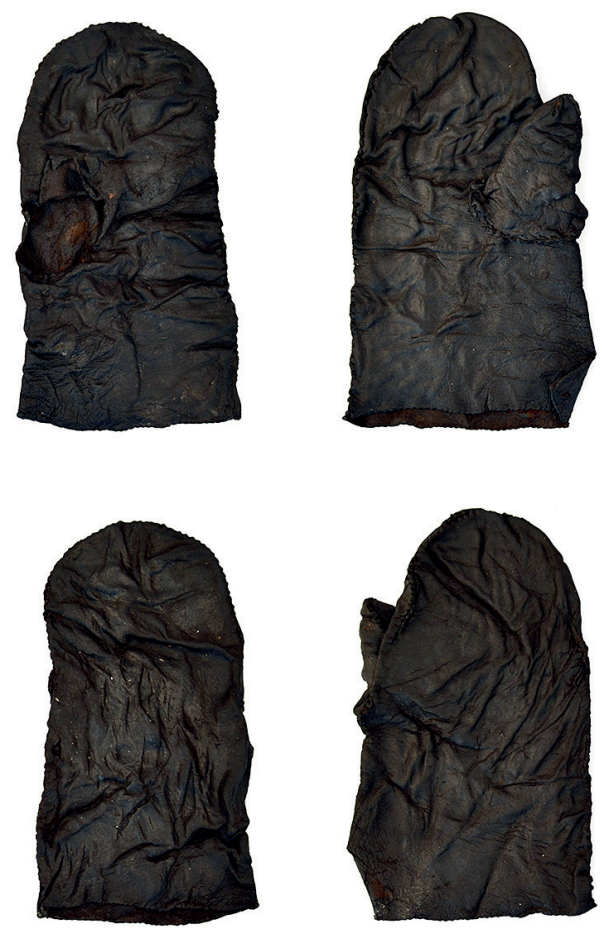

पि口प⿴囗十

Obr. 12. Plzeň čp. 83, Perlová 1, jímka 2. Kožešinové rukavice. Foto M. Zemánková, úprava I. Šlechtová.

Abb. 12. Pilsen Konskriptionsnr. 83, Perlová-Str. 1, Abwassergrube 2. Pelzhandschuhe. Foto M. Zemánková, Bearbeitung I. Šlechtová.

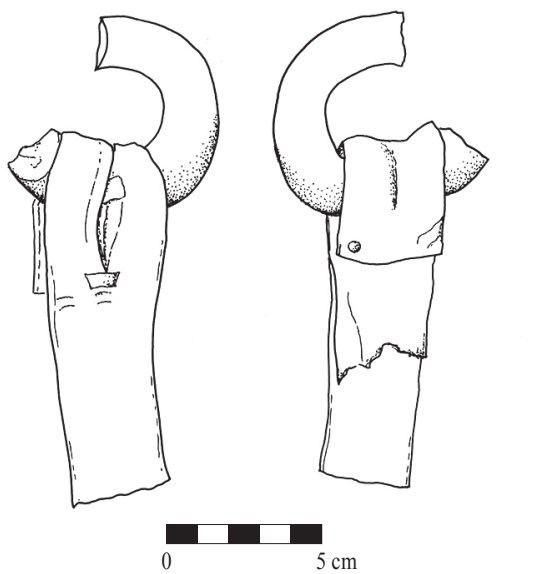

Obr. 13. Plzeň čp. 96, jímka. Koncový fragment opasku s kruhovou přezkou. Kresba V. Dudková.

Abb. 13. Pilsen Konskriptionsnr. 96, Abwassergrube. Endfragment eines Gürtels mit runder Schnalle. Zeichnung V. Dudková. 
původního zásypu nebo jeho části docházelo i v rámci pozdějších rekonstrukcí domu, jako prŕíklad lze uvést čp. $44 \mathrm{v}$ dnešní Malé ulici (Frýda 1982c).

- Odpad byl deponován na jiném místě. V plzeňském prostředí máme doloženo rozhodnutí městské komise, že přes cizí pozemek může být odváděn pouze tekutý odpad, ten pevný musel zůstat na pozemku, odkud pocházel (Macháček 1931, 31). K tomuto účelu sloužily především odpadní jímky situované v zadní části domovních parcel. Přesto je archeologicky doloženo ukládání domovního odpadu včetně fragmentů usní do př́kopu městského opevnění v komplexu Pražské brány ve druhé polovině 15 . století (Široký a kol. 2008, 304). Jak je známo z jiných lokalit v České republice, fragmenty usní mohly společně s jiným odpadem sloužit k zaplnění terénních depresí (Březinová-Selmi Walisová 2016; Richter-Vokolek 1995, 82; Selmi Wallisová 2016), prrípadně byly deponovány v sídlištních vrstvách (např. Dejmal 2015, 53; Hoch 2015, 103; Hoch-Bartík-Běhounková-Malý 2017; Richter-Vokolek 1995, 82; Skalická 2012，54; Šlézar-Faltýnek 2004; Zezula 2004). V této souvislosti je ještě třeba zmínit, že v Plzni byl povrch ulic a náměstí zřejmě poměrně pravidelně udržován a opravován (Nováček-Široký 2000, 296; Široký-Kaiser-Kočár-Nováková 2007, 113).

- Množství nalezených artefaktů mohla negativně ovlivnit také metoda výzkumu. To se týká zejména jímek zkoumaných v rámci sanace plzeňského historického podzemí. Výpln̆ jímek nebyla proplavena, což způsobilo redukci environmentálních pramenů, drobných artefaktů a uvažovat lze i o fragmentech usní. Pro srovnání lze uvést nálezy z jímek v Perlové ulici čp. 66/67, z kterých se díky plavení podařilo získat 329 fragmentů usní. V naprosté většině šlo o řemeslný odpad - útržky a odřezky, výjimkou byly fragmenty bot (Kočár a kol. 2005, 47).

Při snaze určit, zda nálezový soubor fragmentů usní mohl souviset s činností kožedělného řemeslníka v některém z domů, jejichž obyvatelé mohli jímku využívat, je možné v plzeňském prostředí vycházet pouze z komparace archeologických pramenů s těmi písemnými, případně z vyhodnocení složení nálezového souboru z každé odpadní jímky. V Plzni se dosud nepodařilo archeologickým výzkumem získat například ševcovská kopyta, která se našla při výzkumech odpadních jímek v Chrudimi (Frolík-Sigl 1998, 47, 110, 111), Jihlavě (Kochan 2012, 778, 789, tab. 7:34) a Sezimově Ústí (Hrdlička-Richter-Smetánka 1966, 678), v Hradci Králové se kromě kopyt dochovaly také ševcovské jehly (Richter-Vokolek 1995, 83, tab. 118:4, 14, 119:3, 129).

Jak již bylo uvedeno, na základě písemných pramenů je možné největší koncentraci kožedělných řemesel sledovat u Malické (Saské) brány, v dnešní Malé ulici a části Rooseveltovy ulice. Paradoxně se zde však archeologickým výzkumem činnost kožedělných řemesel spolehlivě prokázat nepodařilo. U čp. 44, kde písemné prameny zmiňují činnost ševce v roce 1413 a dalších 


$$
8818
$$


kožedělných řemesel v raném novověku, zř̌ejmě i kvůli již zmíněnému odstranění části původního zásypu odpadní jímky chybí odpovídající archeologické nálezy. Řemeslníci působící v dnešní Malé ulici mohli využívat i odpadní jímky situované v zadních traktech čp. 30 a čp. 31.

Lépe vyznívá komparace písemných a archeologických pramenů v dnešních ulicích Pražská a Perlová. Nálezy z odpadní jímky potvrdily kožedělnou činnost v čp. 80 již na přelomu 14. a 15. století, což ukazuje delší kontinuitu řemesla, než je písemnými prameny uvedené 16. století (Macháček 1930, 220). Činnost ševce po roce 1423 probíhala i v čp. 83 (Strnad 1909, 79), kde se fragmenty usní našly hned ve dvou jímkách. Nálezy řemeslného odpadu se objevily i v odpadních jímkách náležejících k čp. 66 a čp. 67 (Kočár a kol. 2005, 47). Přítomnost kožedělných řemesel v prostoru těchto ulic doložil i archeologický výzkum zásypu př́kopu, který byl součástí komplexu Pražské brány. Z uloženin druhé vývojové fáze, datované do druhé poloviny 15. až počátku 16. století, byl získán soubor 595 fragmentů kožených artefaktů, které byly určeny jako výrobní a řemeslný odpad (Široký a kol. 2008, 301, obr. 25, 303, 304).

Písemné a archeologické prameny se podařilo propojit i u čp. 96 na dnešním náměstí Republiky. Z odpadní jímky byl získán soubor kožených artefaktů, v němž se poměrně marginálně vyskytují části bot (6 kusů), ale převažují odřezky řemenů a pásků (59 kusů). Dále se našly zbytky brašny. Složení tohoto souboru lze zřejmě dát do souvislosti s činností sedláře Petra Snorla, který byl majitelem domu na přelomu 14. a 15. století (Strnad 1909, 61).

Nejpočetnější soubor čítající 216 artefaktů byl součástí zásypu odpadní jímky 3 u čp. 232. Ty byly součástí vrstvy 5 této jímky. Ve vyhodnocení nálezové situace byla tato vrstva uvedena u jímky 2 (Frýda 1981, 314) a informace byla následně publikována (Orna-Dudková 2016, 366). Jímka 2 však nebyla zkoumána po vrstvách (Frýda 1981, 9). U jímky 3 byla mechanická vrstva 5 v hloubce $500-570 \mathrm{~cm}$ od povrchu (Frýda 1981, 51). Díky těmto vrstvám je možné relativně datovat i vrstvu s nálezy usní. Ve vrstvě 1 se nalezl kachel s motivem plzeňského znaku, jehož vznik lze předpokládat po roce 1434 (Frýda 1981, 269). K ukládání vrstvy 5 došlo tedy před tímto rokem. Zhruba 80 \% z kưží nalezených v zásypu jímky jsou vyhozené poškozené části bot (obr. 15-17). Autor výzkumu uložení těchto dílců spojuje s činností ševce (Frýda 1981, 314), která však zřejmě nebyla dlouhodobá (Frýda 1981, 318). Menší počet kůží (21 kusů) byl získán ze zásypu odpadní jímky 2, která však primárně patřila k čp. 229 (Orna-Dudková 2016, 366, 367, obr. 3).

\section{Shrnutí a závěr}

Z dvaceti sedmi odpadních jímek se v Plzni podařilo získat celkem 537 kožených artefaktů. Takřka polovina z nich, tedy 216 kusů, byla vyzvednuta ze zásypu odpadní jímky 3 na čp. 232.

Stejně jako na jiných lokalitách v České republice i v zahraničí největší část souboru tvořily doklady ševcovské produkce. Na základě těchto nálezů lze v obecné rovině konstatovat, že v období pozdního středověku obyvatelé Plzně nosili nízké i vyšší typy obuvi. Mezi méně často nalézané ševcovské výrobky patří trepky. V odpadní jímce 3 na čp. 232 se našel takřka kompletně zachovalý exemplár̆, v zásypu jímky 1 u čp. 119 se vyskytla dřevěná platforma a zdobené pásky, které mohly být součástí tohoto typu obuvi.

Dalšími výrobky, které se podařilo v nálezech plnohodnotně identifikovat, jsou tašky tobolky, pár palcových kožešinových rukavic a koncový fragment opasku s kruhovou přezkou.

Hlavní řešenou otázkou byla možnost ztotožnění nálezového souboru s řemeslnickým provozem. Velkou komplikací byl fakt, že v jednadvaceti ze sedmadvaceti odpadních jímek se podařilo evidovat méně než dvacet fragmentů. To lze vysvětlit několika důvody:

- praktikování domácí opravy obuvi,

- krátké časové působení řemeslníka v domě,

- depoziční a postdepoziční procesy,

- deponování odpadu na jiném místě,

- metoda výzkumu. 
Tab. 2. Výčet odpadních jímek s nálezy kožených artefaktů zapsaných ve sbírce Západočeského muzea v Plzni.

Tab. 2 - Aufzählung der Abwassergruben mit Funden der in der Sammlung des Westböhmischen Museums eingetragenen Lederartefakte.

\begin{tabular}{|c|c|c|c|c|c|c|c|}
\hline 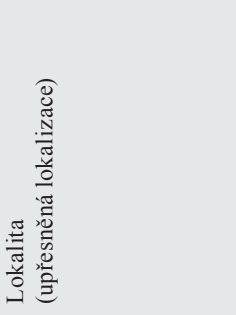 & 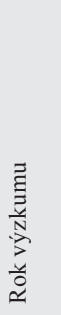 & 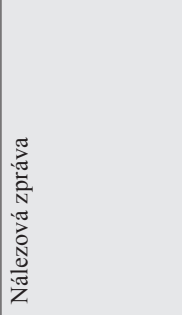 & 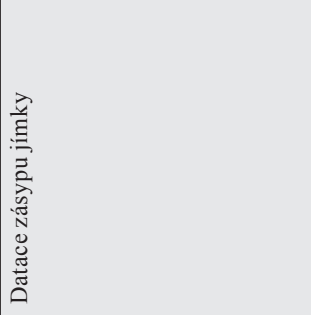 & $\begin{array}{l}\frac{1}{0} \\
\frac{0}{0} \\
: \\
3\end{array}$ & $\frac{\ddot{d}}{\ddot{0}}$ & 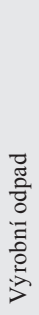 & 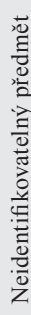 \\
\hline Plzeň čp. 2/3, jímka & 1982 & Frýda 1982 & $\begin{array}{l}\text { 15. století (Orna a kol. 2011, } \\
99-166)\end{array}$ & & 2 & & 1 \\
\hline Plzeň čp. 6, jímka & 1982 & Frýda 1982a & $\begin{array}{l}\text { polovina } 14 . \text { století - polo- } \\
\text { vina } 15 . \text { století (Orna a kol. } \\
2011,99-166)\end{array}$ & & 6 & & \\
\hline Plzeň čp. 9, jímka & 1985 & & $\begin{array}{l}\text { polovina 14. století - počátek } \\
\text { 15. století (Orna a kol. } 2011 \text {, } \\
\text { 99-166) }\end{array}$ & & 2 & & 3 \\
\hline Plzeň čp. 30, jímka & 1986 & & $\begin{array}{l}\text { polovina 14. století - polo- } \\
\text { vina } 15 . \text { století (Orna a kol. } \\
2011,99-166)\end{array}$ & & 6 & & \\
\hline Plzeň čp. 31, jímka & 1989 & & 14.-15. století & & 2 & & 2 \\
\hline $\begin{array}{l}\text { Plzeň čp. 34/35, jímka } \\
\text { (čp. 35) }\end{array}$ & 1982 & Frýda 1982b & $\begin{array}{l}\text { 2. polovina 14. století (Orna } \\
\text { a kol. 2011, 99-166) }\end{array}$ & & 1 & & \\
\hline Plzeň čp. 44, jímka & 1982 & Frýda 1982c & $\begin{array}{l}\text { 1. polovina } 15 \text {. století (Orna } \\
\text { a kol. } 2011,99-166 \text { ) }\end{array}$ & & 1 & & \\
\hline Plzeň čp. 73, jímka 1 & 1975 & Frýda 1975 & $\begin{array}{l}\text { 2. polovina 14. století (Orna } \\
\text { a kol. } 2011,99-166)\end{array}$ & & 2 & & \\
\hline Plzeň čp. 75 , jímka 2 & 1982 & Frýda 1982d & $\begin{array}{l}\text { 14. století (Orna a kol. 2011, } \\
99-166)\end{array}$ & & 3 & & \\
\hline $\begin{array}{l}\text { Plzeň čp. } 79, \text { jímka } \\
\text { (čp. 80) }\end{array}$ & 1968 & Frýda 1972, 111 & $\begin{array}{l}\text { polovina 14. - polovina } \\
\text { 15. století (Orna a kol. 2011, } \\
\text { 99-166) }\end{array}$ & & 21 & & 14 \\
\hline Plzeň čp. 83, jímka 1 & 1968 & Frýda 1972, 112 & $\begin{array}{l}\text { polovina 14. }- \text { 2. polovina } \\
\text { 15. století (Orna a kol. } 2011 \text {, } \\
\text { 99-166) }\end{array}$ & & 8 & & 7 \\
\hline Plzeň čp. 83, jímka 2 & 1968 & Frýda 1972, 112 & $\begin{array}{l}\text { počátek 14. - počátek } \\
\text { 16. století (Orna a kol. 2011, } \\
\text { 99-166) }\end{array}$ & 2 & 12 & & 2 \\
\hline Plzeň čp. 87, jímka 1 & 1986 & & $\begin{array}{l}\text { polovina 14. - polovina } \\
\text { 15. století (Orna a kol. 2011, } \\
99-166)\end{array}$ & & $\begin{array}{l}15 \text { (převážně } \\
\text { části bot) }\end{array}$ & & 4 \\
\hline Plzeň čp. 96, jímka & 1997 & $\begin{array}{l}\text { Nováček-Široký } \\
1997\end{array}$ & $\begin{array}{l}\text { 14.-15. století (Nováček-Ši- } \\
\text { roký } 1997,5)\end{array}$ & 2 & 45 & 2 & 15 \\
\hline Plzeň čp. 113, jímka & 1979 & & $\begin{array}{l}\text { konec } 13 .-1 \text { polovina } \\
\text { 15. století (Orna a kol. 2011, } \\
\text { 99-166) }\end{array}$ & & 7 & & 10 \\
\hline Plzeň čp. 119, jímka 1 & 1980 & Frýda 1980 & $\begin{array}{l}\text { polovina } 14 .-2 \text {. polovina } \\
\text { 15. století (Orna a kol. } 2011 \text {, } \\
\text { 99-166) }\end{array}$ & & 1 & 1 & 1 \\
\hline Plzeň čp. 119, jímka 4 & 1980 & Frýda 1980 & $\begin{array}{l}\text { 14. století (Orna a kol. 2011, } \\
99-166)\end{array}$ & & 9 & 1 & 5 \\
\hline
\end{tabular}




\begin{tabular}{|c|c|c|c|c|c|c|c|}
\hline 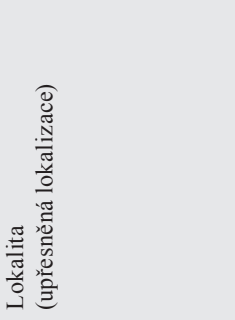 & 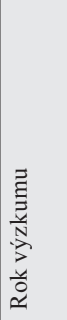 & 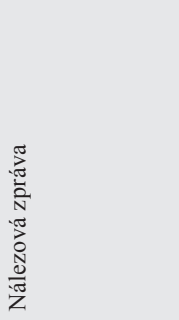 & 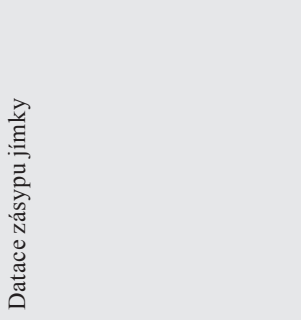 & $\begin{array}{l}\frac{4}{0} \\
\frac{2}{0} \\
\text { 市 }\end{array}$ & $\frac{\ddot{g}}{\ddot{\theta}}$ & 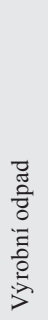 & 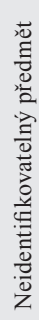 \\
\hline Plzeň čp. 120 , jímka 1 & 1980 & Frýda 1981a & $\begin{array}{l}\text { polovina } 14 . \text { - počátek } \\
\text { 15. století (Orna a kol. 2011, } \\
99-166)\end{array}$ & & 3 & & 7 \\
\hline Plzeň čp. 191, jímka 2 & 1980 & Frýda 1980a & $\begin{array}{l}\text { počátek 14. - polovina } \\
\text { 15. století (Orna a kol. 2011, } \\
99-166)\end{array}$ & & 5 & & \\
\hline Plzeň čp. 207, jímka 1 & 1978 & Frýda 1978 & $\begin{array}{l}\text { polovina } 14 .-1 \text {. polovina } \\
\text { 15. století (Orna a kol. 2011, } \\
99-166)\end{array}$ & & $\begin{array}{l}16 \text { (většinou } \\
\text { podešve } \\
\text { dětských bot) }\end{array}$ & & 7 \\
\hline $\begin{array}{l}\text { Plzeň čp. 232, jímka } 2 \\
\text { (upřesněná lokalizace } \\
\text { čp. 229) }\end{array}$ & 1968 & Frýda 1972, 111 & $\begin{array}{l}\text { počátek 14. }-1 \text {. polovina } \\
\text { 15. století (Orna a kol. 2011, } \\
99-166)\end{array}$ & & 19 & 1 & 1 \\
\hline Plzeň čp. 232, jímka 3 & 1968 & Frýda 1972, 111 & $\begin{array}{l}\text { polovina } 14 .-2 \text {. polovina } \\
\text { 15. století (Orna a kol. 2011, } \\
99-166)\end{array}$ & $\begin{array}{c}1 \\
\text { (trepka) }\end{array}$ & 184 & 13 & 18 \\
\hline Plzeň čp. 237, jímka 3 & 1991 & Frýda 1991 & $\begin{array}{l}\text { polovina } 14 .-2 . \text { polovina } \\
\text { 15. století (Orna a kol. 2011, } \\
99-166)\end{array}$ & & 2 & & \\
\hline Plzeň čp. 262, jímka 1 & 1963 & Nechvátal 1976 & $\begin{array}{l}\text { konec 14. - 1. polovina } \\
\text { 15. století (Nechvátal 1976, } \\
\text { 100) }\end{array}$ & 1 & 13 & & 14 \\
\hline $\begin{array}{l}\text { Plzeň čp. 272, jímka } 2 \\
\text { (upřesněná lokalizace } \\
\text { čp. 276) }\end{array}$ & 1991 & & 15. století & $\begin{array}{c}1 \\
\text { (frag- } \\
\text { menty } \\
\text { brašny) }\end{array}$ & & & \\
\hline Plzeň čp. 289, jímka & 1983 & Frýda 1983b & $\begin{array}{l}\text { polovina 16. - 2. polovina } \\
\text { 17. století (Frýda 1983b) }\end{array}$ & & 7 & & \\
\hline Plzeň čp. 290, jímka & 1983 & Frýda 1983a & $\begin{array}{l}\text { konec } 13 . \text { - 2. polovina } \\
\text { 14. století (Orna a kol. 2011, } \\
\text { 99-166) }\end{array}$ & & 2 & & 3 \\
\hline
\end{tabular}

Při snaze určit, zda nálezový soubor fragmentů usní mohl souviset s činností kožedělného řemeslníka v některém z domů, jehož obyvatelé mohli jímku využívat, je možné v plzeňském prostředí vycházet pouze z komparace archeologických pramenů s těmi písemnými, případně z vyhodnocení složení nálezového souboru z každé odpadní jímky. V Plzni se dosud nepodařilo archeologickým výzkumem získat např́íklad ševcovská kopyta a jehly.

Písemné prameny dokládají největší koncentraci kožedělných řemesel u Malické (Saské) brány, v dnešní Malé ulici a části Rooseveltovy ulice. Zde se však archeologickými doklady činnost kožedělných řemesel spolehlivě prokázat nepodařilo. Lépe vyznívá komparace písemných a archeologických pramenů v dnešních ulicích Pražská a Perlová. Nálezy z odpadních jímek jednoznačně potvrdily kožedělnou činnost v čp. 80 a v čp. 83 a zřejmě i v čp. 66 a čp. 67. Dalším dokladem je soubor 595 fragmentů kožených artefaktů získaný při výzkumu zásypu př́kopu, který byl součástí komplexu Pražské brány. Písemné a archeologické prameny se podařilo propojit 
i u čp. 96 na dnešním náměstí Republiky. Složení zde vyzvednutého souboru lze zřejmě dát do souvislosti s činností sedláře Petra Snorla, který byl majitelem domu na přelomu 14. a 15. století.

Jedinou lokalitou, kterou bylo možné zařadit mezi prokazatelné doklady výroby, byla jímka 3 u čp. 232. Zde byl získán nejpočetnější soubor, který svým charakterem ukazoval na krátkodobé působení ševce.

Soubor kožených artefaktů byl získán ze zásypů plzeňských odpadních jímek, a tomu plně odpovídá jeho charakter. Nalezené kožené fragmenty je možné označit jako odpad, jedná se o evidentně použité a poškozené části především obuvi. U některých větších kožených artefaktů se nabízí otázka, proč nebyly použity a upotřebeny alespoň sekundárně. Ostatně v zásypu odpadních jímek se nachází řada předmětů, jejichž uložení do tohoto typu zahloubeného objektu se z dnešního pohledu nezdá př́liš logické. To se týká např́iklad dřevěných předmětů, protože u tohoto materiálu se předpokládají v důsledku velké odlesněnosti okolí Plzně vyšší náklady na dovoz a nákup dřeva do města (Nováček 2000,30). Nelze však vyloučit, že tyto větší fragmenty kožených artefaktů mohly být do zásypu odpadní jímky vyhozeny z důvodu určitého znehodnocení, které však v důsledku již dříve zmíněných postdepozičních procesů nemusí být v současné době patrné.

Tato studie je výstupem Ústavního úkolu Západočeského muzea v Plzni ÚÚ 2016/03 Kožené artefakty z plzeňských odpadních jímek.

\section{Prameny a literatura}

ATZBACH, R., 2001: Středověká a raně novověká obrácená obuv z Kempten (Allgäu), Německo. In: Obuv v historii. Sborník materiálů ze III. mezinárodní konference 25.-27. září 2000, 184-187. Zlín.

BĚLOHLÁVEK, M., 1950: Sociální rozvrstvení plzeňského obyvatelstva v roce 1470. In: Život Plzeňska I, 134-138, 157-161. Plzeň.

BĚLOHLÁVEK, M. a kol., 1965: Dějiny Plzně I. Plzeň.

BĚLOHLÁVKOVÁ, J., 1989: Nejstarší dochovaná plzeňská městská kniha soudní z let 1407-1411, Sborník archivních prací 39, 121-195.

BŘEZINOVÁ, H., 2007: Textilní výroba v českých zemích ve 13.-15. století. Poznání textilní produkce na základě archeologických nálezů. Dissertationes Archaeologicae Brunenses/Pragensesque 2. Praha - Brno.

BŘEZINOVÁ, H.-SELMI WALLISOVÁ, M., 2016: Odpadní vrstvy a objekty jako pramen poznání stratifikace středověké společnosti - výpověd' mocného smetištního souvrství z Nového Města pražského - Abfallschichten und -objekte als Erkenntnisquelle der Stratifikation der mittelalterlichen Gesellschaft - der Aussagegehalt einer mächtigen Müllkippen-Schichtenfolge aus der Prager Neustadt, AH 41, 179-191.

CEYNOWA, B.-TRAWICKA E., 2016: „Każdy krok zostawia ślad“. Obuwie historyczne ze zbiorów Muzeum Archeologicznego w Gdańsku. Katalog - 'Every Step Leaves A Trace'. Historic Footwear from the Collection of Archaeological Museum in Gdańsk. Catalogue. Gdańsk.

ČAPEK, L.-MILITKÝ, J. a kol., 2016: Historická radnice v Českých Budějovicích ve světle archeologických výzkumů a rozboru hmotných pramenů. Plzeň - České Budějovice.

DEJMAL, M., 2015: Archeologický výzkum v letech 2008-2010. In: Plaček, M.-Dejmal, M. a kol., Veselí nad Moravou. Středověký hrad v říční nivě, 50-79. Brno.

DEJMAL, M.-HOCH, A., 2013: Kožené artefakty z hradu ve Veselí nad Moravou - Lederartefakte von der Burg in Veselí nad Moravou (Wessely an der March), AH 38, 653-671.

DUDKOVÁ, V.-ORNA, J., 2009: A description of medical equipment in the Early Modern period on the basis of finds from the cesspit at house no. 289 in Plzeň - Obraz vybavení lékaře v novověku na základě nálezů z odpadní jímky v domě č. p. 289 v Plzni - Die Ausstattung eines neuzeitlichen Arztes aufgrund der Funde aus Abfallgrube in Konskr.-Nr. 289 in Pilsen, Studies in Post-Medieval Archaeology 3, 501-508.

- 2013: Osobní hygiena v plzeňských domácnostech na sklonku středověku - Die persönliche Hygiene in Pilsener Haushalten zur Neige des Mittelalters, AH 38, 557-568. 
FLODROVÁ, M.-LOSKOTOVÁ, I., 1995: Výrobky brněnských řemeslníků 14. století - Die Erzeugnisse der brünner Handwerker des 14. Jahrhunderts, AH 20, 551-561.

FROLÍK, J.-SIGL, J., 1998: Chrudim v pravěku a středověku. Obrázky každodenního života. Chrudim.

FRÝDA, F., 1972: Plzeň, o. Plzeň-město b), c), d), Výzkumy v Čechách 1969, 111-112.

- 1975: Plzeň, Rooseveltova 10, studna 1. NZ ulož. v archivu odd. starších dějin ZČM v Plzni, čj. 57.

- 1978: Plzeň, Riegrova 3, čp. 207. NZ ulož. v archivu odd. starších dějin ZČM v Plzni.

- 1980: Plzeň čp. 119, čtyři středověké studny a jedna středověká jímka. NZ ulož. v archivu odd. starších dějin ZČM v Plzni, čj. 159.

- 1980a: Zpráva o studni č. 2 v Sedláčkově 9/ Prešovská 9, čp. 191. NZ ulož. v archivu odd. starších dějin ZČM v Plzni, čj. 62.

- 1981: Hmotná kultura středověkého města na základě výzkumu zasypaných středověkých studní v Plzni. FF UK Praha. Nepublikováno.

- 1981a: Plzeň, Františkánská 7. NZ ulož. v archivu odd. starších dějin ZČM v Plzni, čj. 18.

- 1982: Plzeň, nám. Republiky 2, čp. 2/3. NZ ulož. v archivu odd. starších dějin ZČM v Plzni, čj. 181.

- 1982a: Plzeň, nám. Republiky 5, čp. 6. NZ ulož. v archivu odd. starších dějin ZČM v Plzni, čj. 181.

- 1982b: Plzeň, Rooseveltova ul. 13/15, čp. 34/35. NZ ulož. v archivu odd. starších dějin ZČM v Plzni, čj. 187.

- 1982c: Plzeň, Malá ul. 4, čp. 44. NZ ulož. v archivu odd. starších dějin ZČM v Plzni, čj. 179.

- 1982d: Plzeň, Rooseveltova 6, čp. 75, studna 2. NZ ulož. v archivu odd. starších dějin ZČM v Plzni, čj. 188.

- 1983: Nálezy středověkého dřeva z Plzně - Funde mittelalterlichen Holzes aus Plzeň, AH 8, 287-297.

- 1983a: Plzeň čp. 290, nám. Republiky 41, studna 1. NZ ulož. v archivu odd. starších dějin ZČM v Plzni, čj. 186.

- 1983b: Plzeň čp. 289, Dominikánská 2, studna 1. NZ ulož. v archivu odd. starších dějin ZČM v Plzni, čj. 189. - 1991: Plzeň Solní 3. NZ ulož. v archivu odd. starších dějin ZČM v Plzni.

GOUBITZ, O., 2001: Stepping through times: Archeological Footwear from Prehistoric Times until 1800. Zwolle. - 2009: Purses in Pieces: Archaeological Finds of Late Medieval and 16th-century Leather Purses, Pouches, Bags and Cases in the Netherlands. Zwolle.

GREW, F.-NEERGAARD, M., 2001: Shoes and Pattens. Medieval finds from excavations in London 2. London.

GROENMAN-VAN WAATERINGE, W., 1980: Mittelalterliche Lederfunde aus der Lübecker Innenstadt. In: Archäologie in Lübeck, 114-117. Lübeck.

HLAVÁČEK, P., 2002: Analýza usňových dílců. In: Archeologie stř̌edověkého domu v Mostě (čp. 226) The archaeology of a medieval House (No. 226) in Most. Mediaevalia archaeologica 4 (Klápště, J., ed.), 136-157. Praha - Most.

HOCH, A., 2015: Středověká kožedělná produkce z Jihlavy v odrazu hmotné kultury - Medieval leather production in Jihlava as reflected in material culture, Archeologické výzkumy na Vysočině 6, 101-108.

- 2015a: Kožené artefakty. In: Plaček, M.-Dejmal, M. a kol., Veselí nad Moravou. Středověký hrad v říční nivě, 280-298. Brno.

- 2018: Středověká kožedělná produkce z Českých Budějovic v odrazu hmotné kultury, AVJČ 31, 253-277.

HOCH, A.-BARTÍK, J.-BĚHOUNKOVÁ, L.-MALÝ, K., 2017: Středověké kožené artefakty ze Zelného trhu v Uherském Hradišti, Slovácko LVII (2016), 157-173.

HOCH, A.-STANĚK, P., 2015: Kožené artefakty z České ulice v Brně - Artefakte aus Leder aus der Brünner Straße Česká, AH 40, 913-927.

HRDLIČKA, L.-RICHTER, M.-SMETÁNKA, Z., 1966: Výzkum v Sezimově Ústí v roce 1965, AR XVIII, 663-680.

HUSA, V.-PETRÁŇ, J.-ŠUBRTOVÁ, A., 1967: Homo faber. Pracovní motivy ve starých vyobrazeních. Praha.

IGGERS, G. G., 2002: Dějepisectví ve 20. století. Praha.

KABLITZ, K., 2002: Schuhfunde und andere Lederfunde des späten Mittelalters und der frühen Neuzeit aus Hamburg-Altstadt, Hamburg-Hamburg, Hamburg-Moorburg, Hammaburg Neue Folge 13, 137-213.

KLÁPŠTĚ, J., 1983: Studie o středověké studně z Mostu - Studie über einen mittelalterlichen Brunnenaus Most, PA LXXIV, 443-492. 
KLÁPŠTĚ, J., ed., 2002: Archeologie středověkého domu v Mostě (čp. 226) - The archaeology of a medieval House (No. 226) in Most. Mediaevalia archaeologica 4. Praha.

KOČÁR, P. a kol., 2005: Kočár, P.-Klozar, A.-Schneiderwinklová, P.-Kostrouch, F.-Sůvová, Z.-Kočárová, R.-Kyncl, T.-Petr, L.-Hauer, M., Plzeň, čp. 66/67, Perlová 3-5. Nálezová zpráva o záchranném archeologickém výzkumu při odstranění havárie ve sklepích. 2. etapa. Rkp. ulož. v ZIP o. p. s., č. j. 318/05.

KOCHAN, Š., 2012: Dřevěné středověké artefakty z Jihlavy - Mittelalterliche Holzartefakte aus Jihlava, AH 37, 767-795.

MACHÁČEK, F., 1930: Městský dům. In: Plzeň a Plzeňsko. II. díl, 108-223. Plzeň.

- 1931: Dvě studie k dějinám Plzně a Plzeňska. Plzeň.

NOVÁČEK, K., 2000: Středověký dům v Plzni. Archeologický výzkum parcely v Sedláčkově ul. 1 (čp. 187), Sborník Západočeského muzea v Plzni - Historie XV, 5-66.

NOVÁČEK, K.-STOČES, J.-ŠIROKÝ, R.-WASKOVÁ, M., 2014: Počátky Nové Plzně a její vývoj do husitství. In: Dějiny města Plzně I. Do roku 1788, 124-186. Plzeň.

NOVÁČEK, K.-ŠIROKÝ, R., 1997: Plzeň, Náměstí Republiky 8, čp. 96. Zpráva o výsledcích archeologického výzkumu (1997). NZ ulož. v archivu odd. starších dějin ZČM v Plzni, čj. OZAV 118/97.

- 2000: Náměstí v Plzni ve středověku a raném novověku, Wratislavia antiqua. Studia z dziejów Wrocławia 2, 291-297.

NECHVÁTAL, B., 1976: Středověká studna v Plzni - Solní ulici. Archeologické studijní materiály 12. Praha. ORNA, J., 2001: Nálezy středověkých dřevěných předmětů z Plzně. Katalog. CD-ROM. Plzeň.

ORNA, J. a kol., 2011: Keramická produkce města Plzně v období 14. a 15. století. Plzeň.

ORNA, J.-DUDKOVÁ, V., 2016: Možnosti přřřazení předmětů z odpadních jímek v Plzni konkrétním obyvatelům města - Möglichkeiten, Gegenstände aus Pilsner Abwassergruben bestimmten Bürgern der Stadt zuzuordnen, AH 41, 363-374.

PETRÁŇ, J. a kol., 1985: Dějiny hmotné kultury I/2. Praha.

PÍCKA, J.-HŮRKOVÁ, J.-SCHNEIDERWINKLOVÁ, P., 2009: Odpadní jímky z Kašperských hor - Abwassergruben aus Kašperské Hory (Bergreichenstein), AH 34, 103-159.

RECH, M., 2004: Gefunde Vergangehneit. Archäologie des Mittelalters im Bremen. Bremen.

RICHTER, M.-VOKOLEK, V., 1995: Hradec Králové. Slovanské hradiště a počátky středověkého města. Hradec Králové.

SELMI WALLISOVÁ, M., 2016: Archeologický výzkum „Jámy“ na Novém Městě pražském - Archaeological excavation of „Jáma“ in the New Town of Prague, Staletá Praha 32, č. 2, 84-108.

SHROMÁŽDILOVÁ, I., 2000: Kožedělná výroba ve středověkém Brně, Brno v minulosti a dnes XV, 33-61.

- 2001: Kožedělná výroba v Uherském Hradišti ve středověku, Slovácko XLII (2000), 149-157.

SCHNACK, CH., 1994: Mittelalterliche Lederfunde aus Konstanz. Grabung Fischmarkt. Stuttgart.

SKALICKÁ, P., 2012: Středověká obuv. In: Vojkůvková, K.-Zezula, M. a kol., Předměty vyprávějí... Hmotná kultura středověké a raně novověké Opavy ve světle nálezů z archeologických výzkumů v prostoru bývalé Radniční ulice a v areálu opavského pivovaru, 54-55. Opava - Ostrava.

STRNAD, J., 1887: Několik úryvků z dějin královského města Plzně z dob před válkou husitskou. In: Čtrnáctá zpráva za dvacátý čtvrtý školní rok c. k. českého státního vyššího real. gymnasia v Plzni uveřejněná na konci školního roku 1886/1887 ředitelstvím ústavu, 3-22. Plzeň.

- 1891: Listář královského města Plzně a druhdy poddaných osad. Část I. Od r. 1300-1450. Plzeň.

- 1905: Listář královského města Plzně a druhdy poddaných osad. Část II. Od r. 1450-1526. Plzeň.

- 1909: Nejstarší místopis Plzně do válek husitských, Sborník městského historického musea v Plzni I, 54-87.

ŠIROKÝ, R. a kol., 2008: Široký, R.-Kočár, P.-Hlaváć, J.-Kaštovská, K.-Kostrouch, F.-Kyncl, J.-Militký, J.-Pokorný, P.-Postránecká, K.-Schneiderwinklová, P., Př́ikop středověkého opevnění města Plzně: archeologický a environmentální výzkum v prostoru zaniklé Pražské brány, Forum urbes medii aevi V. Městské fortifikace ve vrcholně středověkých zeměpanských městech střední Evropy, 272-311.

ŠIROKÝ, R.-KAISER, L.-KOČÁR, P.-NOVÁKOVÁ, K., 2007: Sedláčkova ulice v Plzni ve světle archeologického výzkumu. K podobě veřejných prostranství středověkých měst, Forum urbes medii aevi IV, 94-117.

ŠLÉZAR, P.-FALTÝNEK, K., 2004: Litovel (okr. Olomouc), Centrum města, PV 45, 204-207.

ŠMEJDA, L., 1999: K hmotné kultuře Vysokého Mýta ve středověku, Mediaevalia Archeologica 1, 169-192. 
VOLKEN, M., 2014: Archaeological Footwear: Development of shoe patterns and styles from Prehistory till the 1600s. Assen.

VYSKOČILOVÁ, G.-ORLITA, A.-SOUČKOVÁ, M.-ŠEVČÍK, R., 2016: Kůže, useň, pergamen. Studijní materiály k předmětům C5984, C5985 a C8910. PřF MU Brno.

WAGNER, E.-DROBNÁ, Z.-DURDÍK, J., 1956: Kroje, zbroj a zbraně doby předhusitské a husitské. Praha. WIKLAK, P., 1960: Obuwie gdańskie w X-XIII wieku, Gdańsk wczesnośrednowieczny III, 7-101.

WINTER, Z., 1890: Kulturní obraz českých měst. Život veřejný v XV. a XVI. věku I. Praha.

- 1893: Dějiny kroje v zemích českých od počátku století XV. po dobu bělohorské bitvy. Praha.

WYWROT-WYSZKOWSKA, B., 2008: Skórnictwo w lokacyjnym Kolobrzegu. XIII-XV wiek. Sczczecin. - 2009: Późnośredniowieczne zabytki skórzane - problemy badawcze i mozliwości interpretacyjne. In: Studia nad średniowiecznym skórnictwem (Kowalska, A. B.-Wywrot-Wyszkowska, B., edd.). Szczecin. ZEZULA, M., 2004: Opava, Pekařská ulice, parcela č. 327 a 324, PV 45, 228-229.

\section{Zusammenfassung}

Erkenntnisse über die lederverarbeitende Produktion der Königsstadt Pilsen in der Zeit des Spätmittelalters und der frühen Neuzeit anhand von Funden von aus Abwassergruben stammenden Lederartefakten

Aus siebenundzwanzig Abwassergruben konnten in Pilsen insgesamt 537 Lederartefakte geborgen werden. Fast die Hälfte von ihnen, also 216, wurden aus der Verfüllung der zu Konskriptionsnummer 232 gehörenden Abwassergrube 3 gehoben.

Ebenso wie bei anderen in der Tschechischen Republik und im Ausland befindlichen Fundstellen bildeten Belege der Produktion des Schusterhandwerks den größten Teil dieser Kollektion. Anhand dieser Funde kann festgehalten werden, dass die Bewohner von Pilsen in der Zeit des Spätmittelalters niedrige und höhere Schuhwerktypen getragen haben. Zu den weniger häufig gefundenen Schustererzeugnissen zählen Trippen (Unterschuhe aus Holz). In Abwassergrube 3 von Konskriptionsnummer 232 fand man ein fast komplett erhaltenes Exemplar, in der Verfüllung von Abwassergrube 1 bei Konskriptionsnummer 119 dann eine Holzplattform und verzierte Bänder, die Bestandteile dieses Schuhwerktyps gewesen sein konnten.

Weitere Erzeugnisse, die in den Funden vollständig identifiziert werden konnten, sind Taschen, ein Paar Pelzfäustlinge und das Endfragment eines Gürtels mit runder Schnalle.

Die hauptsächlich geklärte Frage war die Möglichkeit, den Fundkomplex mit einem Handwerksbetrieb zu identifizieren. Eine große Schwierigkeit dabei war die Tatsache, dass in einundzwanzig von siebenundzwanzig Abwassergruben weniger als zwanzig Fragmente erfasst werden konnten. Dies lässt sich auf mehrere Ursachen zurückführen:

- Schuhwerk wurde zuhause repariert

- nur kurzfristige Tätigkeit eines Handwerkers im Haus

- depositäre und postdepositäre Prozesse

- Entsorgung des Abfalls an einem anderen Ort

- durch die Grabungsmethode.

Bei dem Bestreben zu bestimmen, ob der Fundkomplex der Lederfragmente mit der Tätigkeit eines Lederarbeiters in einem der Häuser zusammenhängen konnte, deren Bewohner die Abwassergrube haben nutzen können, kann man in der Umgebung von Pilsen nur von einem Vergleich der archäologischen Quellen mit den entsprechenden schriftlichen Quellen ausgehen, bzw. gegebenenfalls die Zusammensetzung des Fundkomplexes einer jeden Abwassergrube auswerten. Durch eine archäologische Grabung ist es in Pilsen bislang nicht gelungen, beispielsweise Schusterleisten und -nadeln zu entdecken. 
Die schriftlichen Quellen belegen die größte Konzentration von lederverarbeitenden Gewerben am Malitzer Tor (Sachsentor) in der heutigen Straße Malá und einem Teil der Straße Rooseveltova. Jedoch ist es dort nicht gelungen, Tätigkeiten der lederverarbeitenden Gewerbe zuverlässig mit archäologischen Belegen nachzuweisen. Besser fiel der Vergleich der schriftlichen und archäologischen Quellen in den heutigen Straßen Pražská und Perlová aus. Die Funde aus den Abwassergruben haben bei Konskriptionsnummer 80 und 83 und offenbar auch bei Konskriptionsnummer 66 und 67 eindeutig eine lederverarbeitende Tätigkeit bestätigt. Ein weiterer Beleg ist eine Kollektion von 595 Fragmenten von Lederartefakten, die bei der Untersuchung der Verfüllung eines Grabens entdeckt wurden, der zu dem Komplex des Prager Tores gehörte. Die schriftlichen und archäologischen Quellen konnten auch bei Konskriptionsnummer 96 auf dem heutigen Platz der Republik miteinander in einen Zusammenhang gebracht werden. Die Zusammensetzung der dort gehobenen Kollektion kann man offenbar mit der Tätigkeit des Sattlers Petr Snorl in Verbindung bringen, der zur Wende des 14. und 15. Jahrhunderts Besitzer dieses Hauses war.

Die einzige Fundstelle, die zu den nachweislichen Produktionsbelegen gezählt werden konnten, war Abwassergrube 3 bei Konskriptionsnummer 232. Dort wurde die zahlreichste Kollektion entdeckt, die ihrem Charakter nach auf die kurzfristige Tätigkeit eines Schusters hindeutete.

Die Sammlung an Lederartefakten wurde in den Verfüllungen von Pilsner Abwassergruben entdeckt, was auch voll und ganz ihrem Charakter entspricht. Die gefundenen Lederfragmente können als Abfall bezeichnet werden, bei denen es sich um gebrauchte und beschädigte Teile von vor allem Schuhwerk handelt. Bei einigen größeren Lederartefakten drängt sich die Frage auf, warum sie nicht gebraucht oder zumindest sekundär verwertet wurden. Es kann jedoch nicht ausgeschlossen werden, dass diese größeren Fragmente von Lederartefakten aufgrund einer gewissen Entwertung in die Verfüllung der Abwassergruben entsorgt wurden, die jedoch infolge postdepositärer Prozesse heute nicht ersichtlich sein muss.

Die vorliegende Studie ist ein Output der Institutsaufgabe des Westböhmischen Museums in Pilsen ÚÚ 2016/03 Lederartefakte aus Pilsner Abwassergruben.

Mgr. Jiří Orna, Západočeské muzeum v Plzni, Kopeckého sady 2, 30100 Plzeň, Česká republika, jorna@zcm.cz

Mgr. Veronika Dudková, Západočeské muzeum v Plzni, Kopeckého sady 2, 30100 Plzeň, Česká republika, vdudkova@zcm.cz 
